\title{
Assessment of LULC and climate change on the hydrology of Ashti Catchment, India using VIC model
}

\author{
NAREndra Hengade and T I Eldho* \\ Department of Civil Engineering, Indian Institute of Technology Bombay, Mumbai 400 076, India. \\ *Corresponding author.e-mail: eldho@civil.iitb.ac.in
}

The assessment of land use land cover (LULC) and climate change over the hydrology of a catchment has become inevitable and is an essential aspect to understand the water resources-related problems within the catchment. For large catchments, mesoscale models such as variable infiltration capacity (VIC) model are required for appropriate hydrological assessment. In this study, Ashti Catchment (sub-catchment of Godavari Basin in India) is considered as a case study to evaluate the impacts of LULC changes and rainfall trends on the hydrological variables using VIC model. The land cover data and rainfall trends for 40 years (1971-2010) were used as driving input parameters to simulate the hydrological changes over the Ashti Catchment and the results are compared with observed runoff. The good agreement between observed and simulated streamflows emphasises that the VIC model is able to evaluate the hydrological changes within the major catchment, satisfactorily. Further, the study shows that evapotranspiration is predominantly governed by the vegetation classes. Evapotranspiration is higher for the forest cover as compared to the evapotranspiration for shrubland/grassland, as the trees with deeper roots draws the soil moisture from the deeper soil layers. The results show that the spatial extent of change in rainfall trends is small as compared to the total catchment. The hydrological response of the catchment shows that small changes in monsoon rainfall predominantly contribute to runoff, which results in higher changes in runoff as the potential evapotranspiration within the catchments is achieved. The study also emphasises that the hydrological implications of climate change are not very significant on the Ashti Catchment, during the last 40 years (1971-2010).

\section{Introduction}

The impact of change in rainfall trends on water resources has been an important concern in the recent years. Climate change impacts the hydrological cycle, and the change in rainfall trends is one such implication of climate change. The change in rainfall trends is linked with many water resources-related problems, such as drought, flooding, water logging, etc. India receives about $85 \%$ of its total rainfall during monsoon (i.e., in the months of JJAS), and agricultural activities are completely dependent on the monsoon rainfall.
Hence, small changes in rainfall trends could impact the agricultural developments and, eventually, the economic development of the country. Hydrological models are widely used to study the impact of climate change on the hydrologic cycle and management of water resources systems (Lin et al. 2007, 2010). Many mesoscale hydrological models (MHMs) have been developed over the past couple of decades (Nijssen et al. 2000, 2001; Maurer et al. 2002; Hurkmans et al. 2008) to simulate hydrological processes. MHMs provide a link between general circulation models (GCMs) and water resource systems (Qiao et al. 2014). Most of

Keywords. Land cover; rainfall trends; climate change; mesoscale hydrological model; variable infiltration capacity model. 
the MHMs use already derived parameters, which are standards for each land surface class and varies for various classes (Nijssen et al. 2001). Standard parameter for different land cover classes simplifies the application and allows the use of available standard global datasets. However, it introduces several sources of uncertainties in calibrating the model as the number of governing parameters is standardised and greatly reduced. Irrespective of several limitations, MHMs are powerful and widely used tools to study spatial and temporal hydrologic variability, over a large geographic domain. The variable infiltration capacity (VIC) model (Liang et al. 1994, 1996; Cherkauer and Lettenmaier 1999) is one of the examples of MHMs. It allows evaluating spatial hydrologic variability, impact of land cover change and impact of climate changes over a large geographic domain.

Trend analysis of the hydrological variables provides additional information regarding the behaviour of data, which reflects the changes in the hydrological cycle. Trend analysis of hydrological variables is necessary to detect the long-term changes and statistics of variables, such as rainfall and temperature (Chen et al. 2007; Burns 2008). The hydrological model combined with statistical methods has been a useful tool to understand the long impact of climate change on the hydrological processes. Although, the VIC model has been used on a continental scale (Maurer et al. 2002) and global scale (Nijssen et al. 2000, 2001), the performance of the VIC in the Indian monsoon region has not been widely explored.
In the present study, the VIC model was applied to simulate the hydrological variables in Ashti Catchment, within the Godavari river basin. The model simulated and observed discharges were compared to understand the capabilities and efficiency of the VIC model. The objectives of the current study are threefold: (1) To evaluate the VIC model's performance to estimate the hydrological variables for larger catchments; (2) to understand the impact of rainfall trends on hydrological variables; (3) to evaluate the impact of different land cover classes on the hydrological variables. Geographical information systems (GIS) was used to handle the global data sets for an understanding on the distribution of the physical characteristics of the catchments and efficient data processing.

\section{Study area and data}

The Ashti Catchment $\left(50,990 \mathrm{~km}^{2}\right)$ is the subcatchment of Godavari river basin $\left(312,800 \mathrm{~km}^{2}\right)$ located in the Deccan plateau, India. The geographical setting of the basin is shown in figure 1 . The Ashti Catchment is situated between longitudes $78^{\circ} 06^{\prime}-80^{\circ} 45^{\prime} \mathrm{E}$ and latitudes $19^{\circ} 41^{\prime}-22^{\circ} 50^{\prime} \mathrm{N}$. The catchment covers the areas in Maharashtra and Madhya Pradesh states. The Ashti station is located on the Wainganga, which is the sub-tributary of Pranhita River. The Pranhita tributary is the largest tributary of the Godavari River. The average annual rainfall in Ashti Catchment is $1086 \mathrm{~mm}$, which varies largely in space and time.

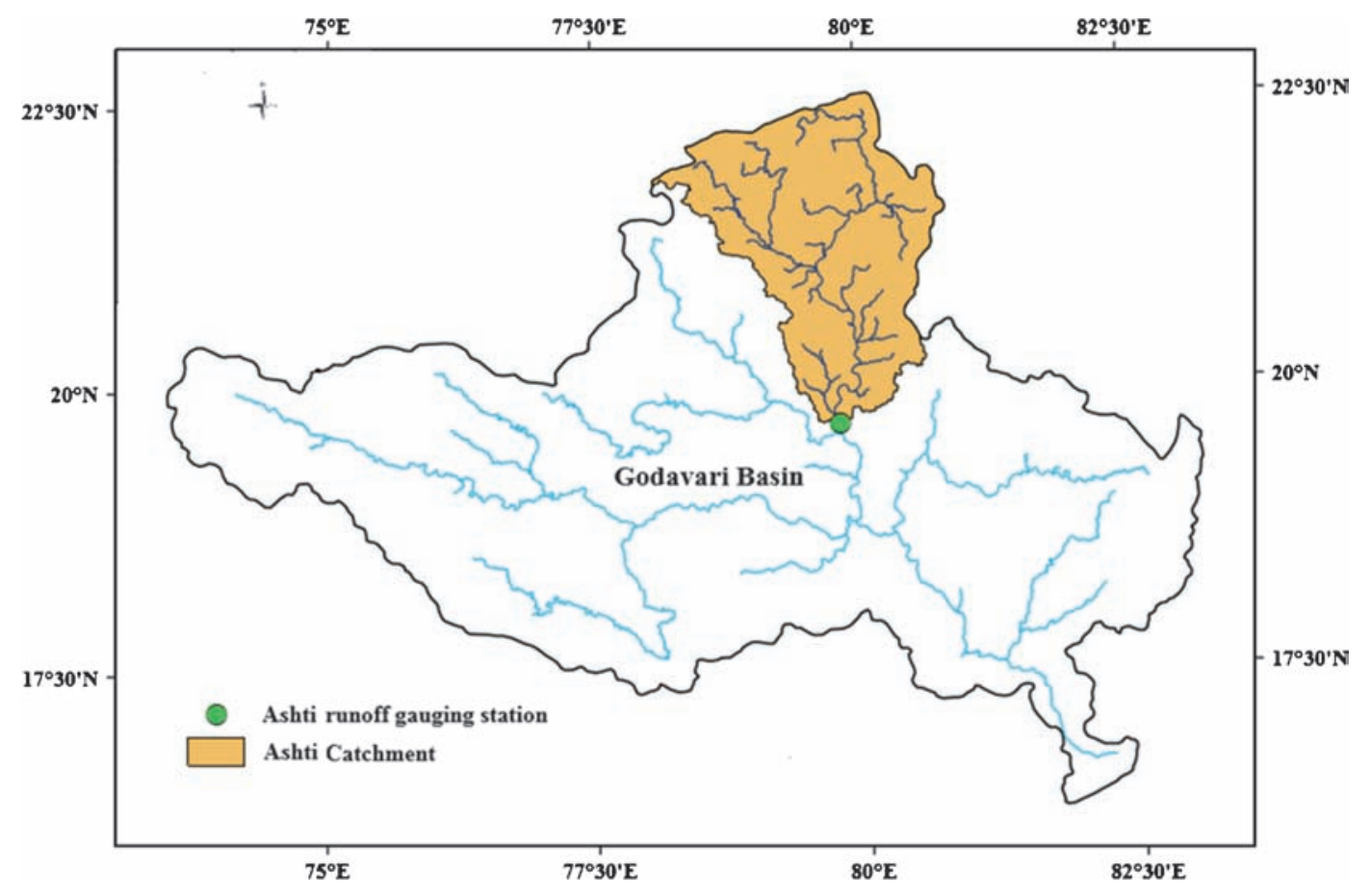

Figure 1. Location map: Ashti Catchment. 
The elevation of the catchment varies from 144 to $1036 \mathrm{~m}$ above msl.

The shuttle radar topography mission (SRTM) dataset with digital elevation model (DEM) of 90 $\mathrm{m}$ spatial resolution has been used to delineate the Ashti Catchment boundary, as presented in figure 2(a). The land cover map was obtained from an Advanced Very High Resolution Radiometer (AVHRR) at $1 \mathrm{~km}$ spatial resolution as presented in figure 2(b). Food and Agriculture

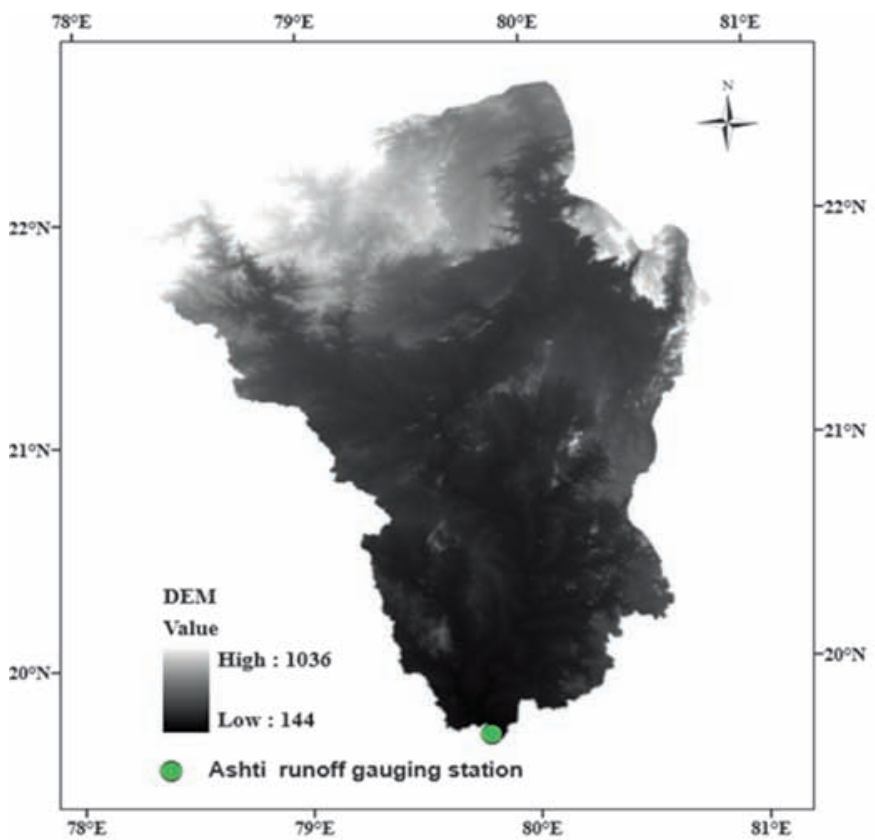

(a)

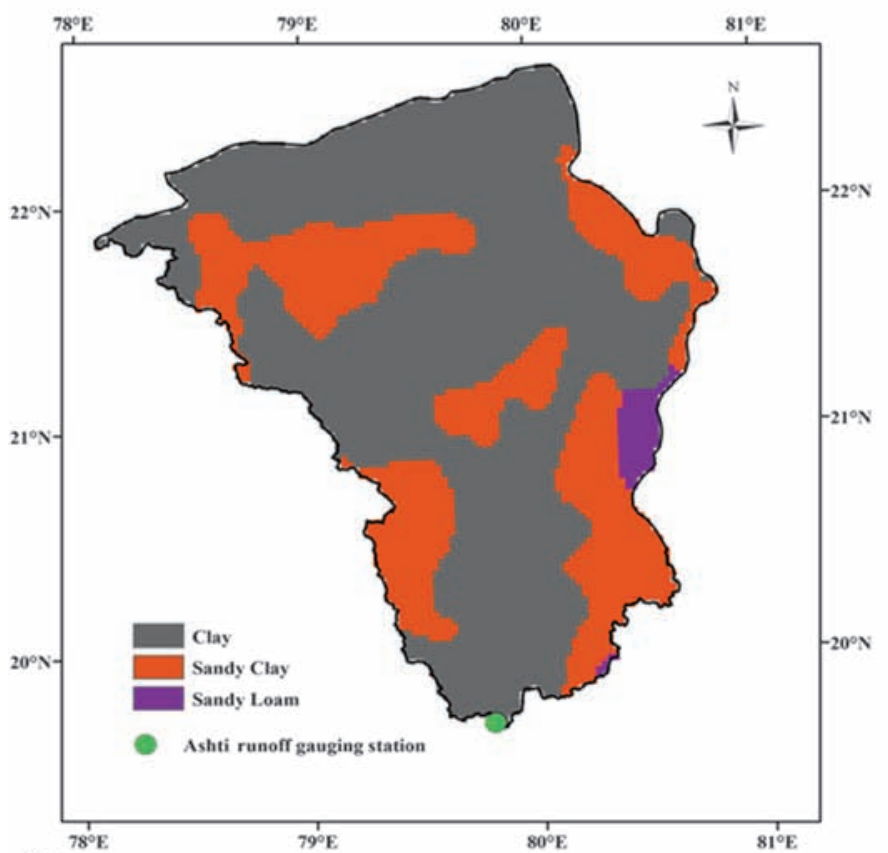

(c)
Organization of United Nations (FAO) digitised soil map of the world which was employed to extract the soil information as presented in figure $2(\mathrm{c})$. In the catchment, the dominance of clay and sandy clay was observed. Since the VIC model formulation works on a grid basis, a square grid of area $25 \times 25 \mathrm{~km}^{2}$ was generated over the study region of Ashti Catchment. There are 104 grids falling in the basin as shown in figure 2(d). Meteorological variables, such as daily precipitation,

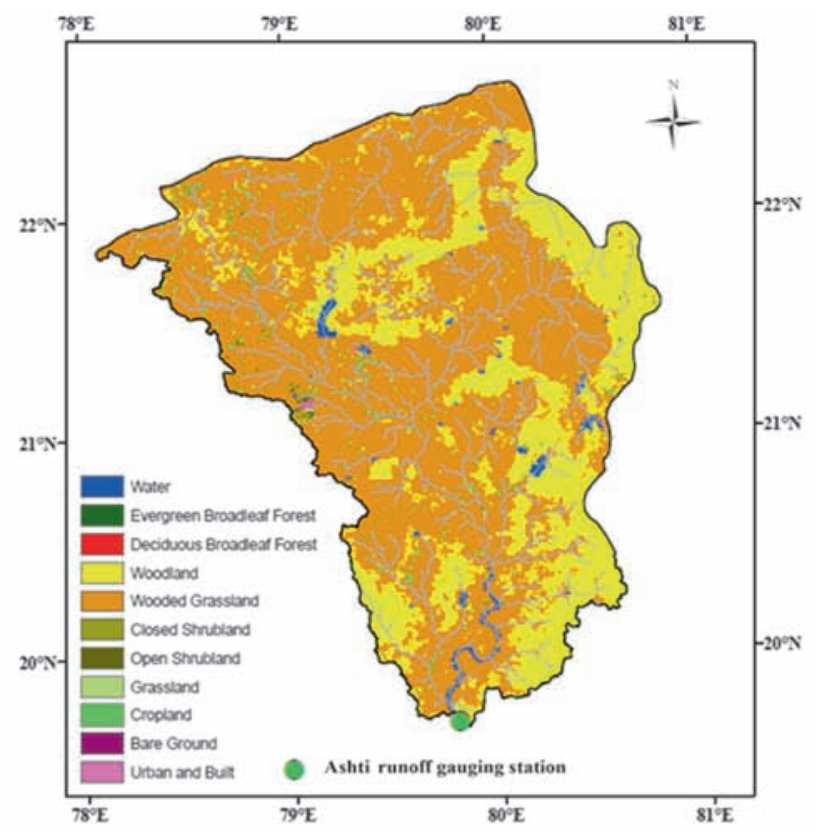

(b)

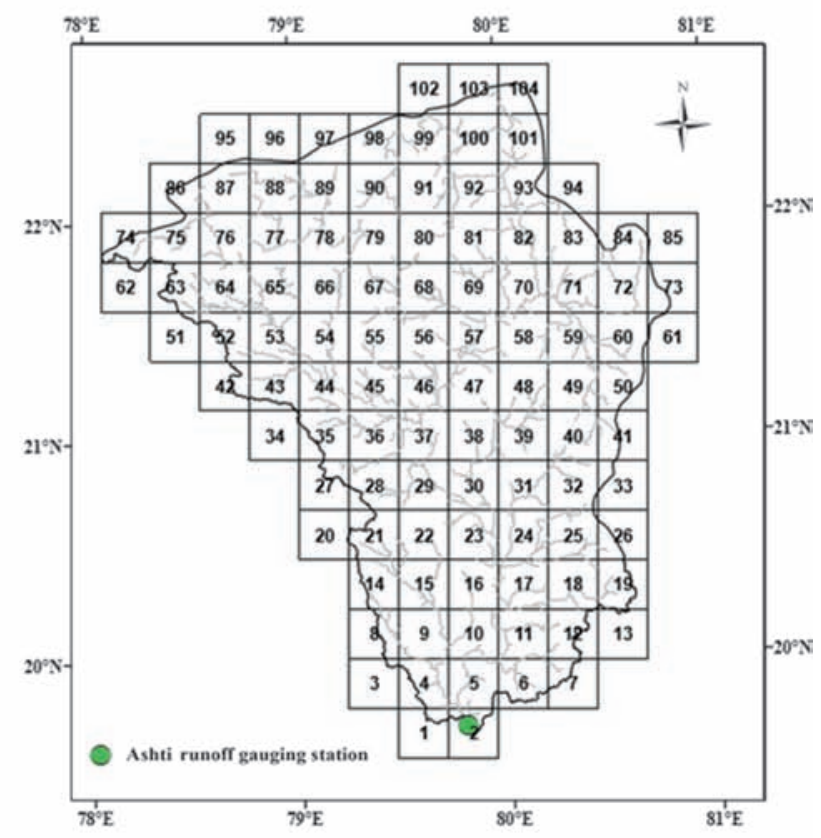

(d)

Figure 2. Ashti Catchment. (a) DEM (SRTM), (b) LULC (AVHR), (c) soil map (FAO) and (d) grids with number. 
daily maximum temperature, daily minimum temperature and wind speed, were used as input to the VIC model. The $0.25^{\circ} \times 0.25^{\circ}$ precipitation; and $1^{\circ} \times 1^{\circ} \mathrm{min}$. and max. temperatures gridded data of India Meteorological Department (IMD) have been employed for the period of 1971-2010 (Rajeevan et al. 2005). The National Centers for Environment Prediction's (NCEP/NCAR) reanalysis data (Kalnay et al. 1996) was used as input data for wind speed at $2.5^{\circ} \times 2.5^{\circ}$ resolutions. Soil properties, namely, soil texture, bulk density and saturated hydraulic conductivity (FAO 2003), are used in the current study. All soil parameters have been derived at each grid cell for two soil layers, the first layer with a depth of 300 $\mathrm{mm}$ below the ground level and the second layer with a depth of $700 \mathrm{~mm}$ below the first layer, to initiate the model. The observed stream flows at Ashti runoff gauging station were collected from Central Water Commission (CWC), Govt. of India.

\section{Material and methodology}

\subsection{VIC model}

VIC model is a spatially distributed land surface macro-scale hydrologic model that operates at grid cell level. The land surface is divided into multiple uniform grid cells to cover the study area. Input parameters such as meteorological forcing, soil, topography, vegetation classes are prepared at each grid cell. The VIC model is formulated for larger catchments/river basins with fairly coarse grids and it accepts the meteorological data input directly from global gridded databases or from GCMs. The large spatial resolution is compensated by incorporating sub-grid variability, which describes variations in the surface parameters as well as meteorological forcing parameters.

VIC adopted the conceptual ARNO baseflow model (Todini 1996) to obtain the subsurface runoff from the bottom soil layer. The onedimensional Richard's equation is employed to formulate the vertical moisture transfer between soil layers. The fluxes estimated by the VIC model at grid cell contain fluxes of surface runoff, evapotranspiration, baseflow, etc. These fluxes were transferred to the routing model (Lohmann et al. 1996, 1998). It is used to route the surface runoff and base flow to the outlet of the respective grid cell and eventually at the outlet of catchment/basin through the drainage system. The output routing model permits comparisons between the modelsimulated discharges and observed stream flows at the gauging stations.

\subsection{Establishing the VIC model for the Ashti Catchment}

Four major input files that are required to set the VIC model input database include the following:

- Vegetation parameter file,

- vegetation library file,

- soil parameter file, and

- forcing files.

The data in these entire files are stored in ASCII format. As VIC model works on a grid basis, a square grid of area $25 \times 25 \mathrm{~km}^{2}$ was generated over the study region of Ashti Catchment as shown in figure 2(d). The generated grid network for the catchment area was used to overlay with other thematic layers such as DEM, soil and land cover. Hence, the grid wise distribution of various parameters and properties within the catchment was defined. Elevation, slope parameter and flow direction (figure 3a) were generated using DEM, and fraction of the grids at the boundary of the catchment (figure $3 \mathrm{~b}$ ) and extracted to process the actual catchment area out of the grid area. The flow direction and fraction files were used by the flow routing model.

\subsection{Land cover datasets}

The land cover map was obtained from the advanced very high resolution radiometer (AVHRR) data generated by University of Maryland, Department (UMD) of Geography. Figure 2(b) presents $1 \mathrm{~km}$ spatial resolution, global land cover map (19811994) for the Ashti Catchment. It showed the dominance of wooded grassland $(62.46 \%)$ and woodland $(22.61 \%)$ within the catchment area. The number of vegetation types, their fractional coverage, root depth and its fraction were derived for each grid, separately. The percentage of different land cover classes with the catchment area were tabulated in table 1.

\subsection{De-trended meteorological forcing data}

The grid-wise trend analysis is proposed for meteorological forcing data, i.e., rainfall, maximum temperature, minimum temperature and wind speed. The de-trended meteorological forcing data was required to evaluate the change in the hydrological variables caused by changes in trends of rainfall, maximum temperature, minimum temperature and wind speed. It was assumed that the long-term change in trends of meteorological data was caused by climate change.

The trend analysis operates on a daily time series of the meteorological data, separately at each grid level, e.g., daily rainfall series at any grid $R(i)$, 


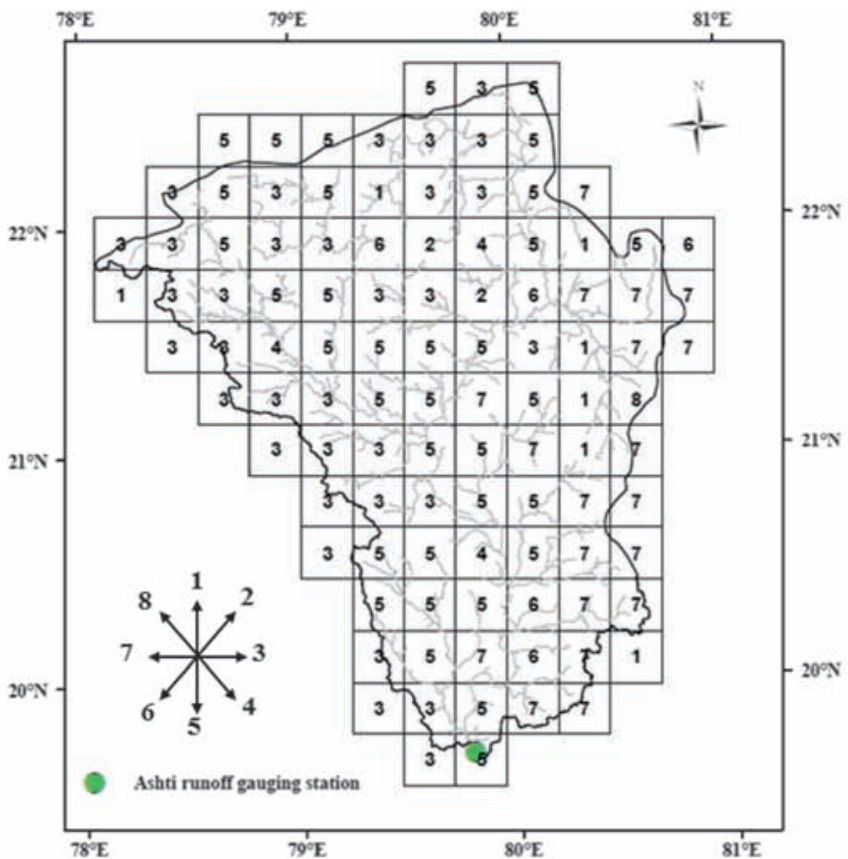

(a)

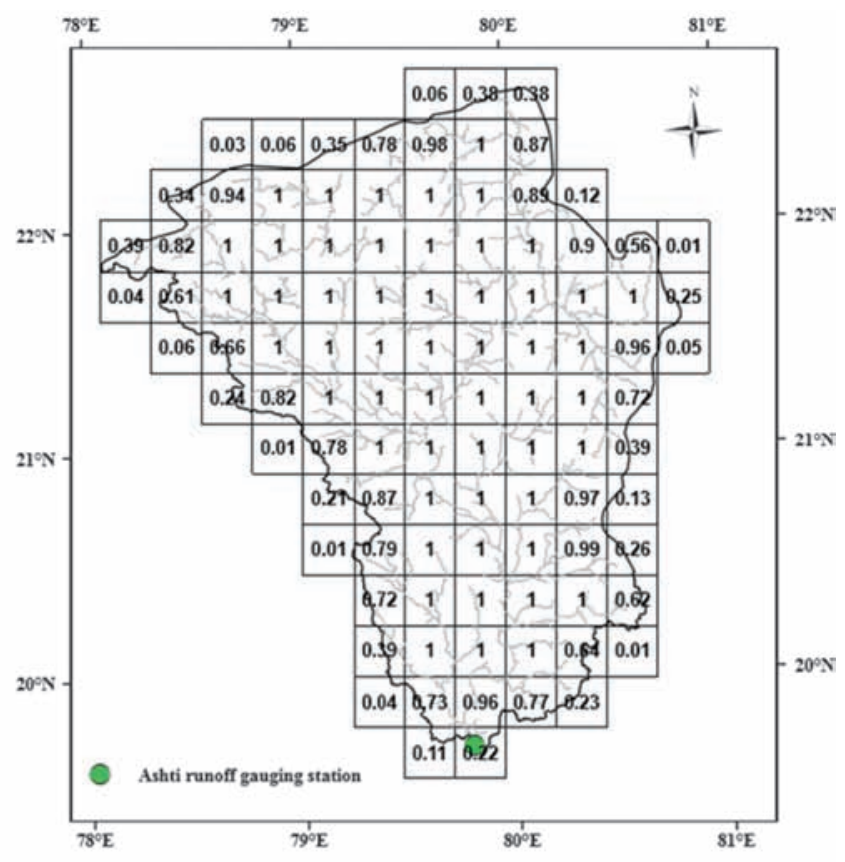

(b)

Figure 3. Ashti Catchment. (a) Flow direction and (b) fraction.

Table 1. AVHRR land use data for Ashti Catchment.

\begin{tabular}{lcc}
\hline Land use & Area $\left(\mathrm{km}^{2}\right)$ & Area $(\%)$ \\
\hline Water & 568 & 1.11 \\
Evergreen broadleaf forest & 94 & 0.19 \\
Woodland & 11,528 & 22.61 \\
Wooded grassland & 31,846 & 62.46 \\
Closed shrubland & 316 & 0.62 \\
Open shrubland & 4973 & 9.75 \\
Grassland & 116 & 0.23 \\
Cropland & 326 & 0.64 \\
Urban and built & 1222 & 2.40 \\
\hline
\end{tabular}

where $i=1,2,3,4, \ldots, n$ and $n$ is the length of the data record (40 years). The trend analysis was done separately for the different seasons, i.e., June-July-August-September (JJAS), October-November (ON), December-JanuaryFebruary (DJF) and March-April-May (MAM). At each grid level, the daily data of meteorological forcing parameters were divided into four seasons. A series of the seasonal sum for 40 years (40 data points) was generated for each season. Thus, 4-data series (four seasons) with 40 data points (40 years) were generated and used for further trend analysis at each grid using equation (1).

Observed seasonal sum $=\sum_{i=1}^{N \text {-days }}$

(meteorological forcing parameter), where $i$ is the start day of the season and $N$-days is the number of days within the respective season.

$\mathrm{P}$-value criterion is considered to decide the statistically significant $(95 \%)$ trend within the particular data series. The de-trended seasonal sum was computed by removing the significant slope in the observed data as presented by equation (2).

$$
\begin{aligned}
& (\text { De-trend seasonal sum })_{i=1}^{j=40} \\
& \quad=(\text { observed seasonal sum })_{i=1}^{j=40}-\text { slope. }
\end{aligned}
$$

The daily de-trended data series for a particular season was generated using equation (3).

De-trend daily data $=$ observed daily data

$$
\times \frac{\text { de-trend season sum }}{\text { observed seasonal sum }} \text {. }
$$

Thus, the series of de-trended meteorological forcing data with the same length as that of the observed data were generated.

\section{Results and discussion}

The present study attempts to model the hydrology of the Ashti Catchment using the VIC-2L model. For this purpose, the VIC land surface hydrological model was calibrated and validated by comparing the observed and simulated stream flows at the Ashti runoff gauging station with a catchment area of $50,990 \mathrm{~km}^{2}$. The statistically 
significant rainfall trends (95\%) were removed grid wise and the impact of the rainfall trends on water balance over the Ashti Catchment was evaluated. The land cover was mapped using AVHRR (1981-1994). The impact of the change in land cover on evapotranspiration was also evaluated and analysed.

\subsection{Change in trends of meteorological forcing data}

Grid-wise trend analysis was done for meteorological forcing data, i.e., rainfall, maximum temperature, minimum temperature and wind speed. Figure 4 represents the seasonal sum of the observed and de-trended monsoon rainfall for increasing and decreasing trends at grid level. The de-trended data series for each meteorological forcing data was obtained by removing the significant increasing/decreasing trends in the observed data series over the period of 40 years (1971-2010). Figure 5 represents the grids with statistically significant $(95 \%)$ seasonal trends for rainfall over the
Ashti Catchment. The decreasing rainfall trends at six grid locations as well as increasing rainfall trend at one grid location, out of 104 grids, were observed for the monsoon period (JJAS) only. Hence, it could be concluded that impact of climate change was not considerable over the Ashti Catchment during the last 40 years (1971-2010). No statistically significant (95\%) trends were observed for maximum temperature, minimum temperature and wind speed. Table 2 shows the ranges of meteorological forcing data for observed and de-trended scenarios for 40 years (1971-2010). The de-trended meteorological forcing data was employed in the VIC model to understand the impact of trends in meteorological data on the streamflow, and the results are discussed in section 4.3.

\subsection{VIC model calibration and validation}

The hydrological responses using streamflow can be measured with high accuracy in comparison with other water fluxes within the catchment. The

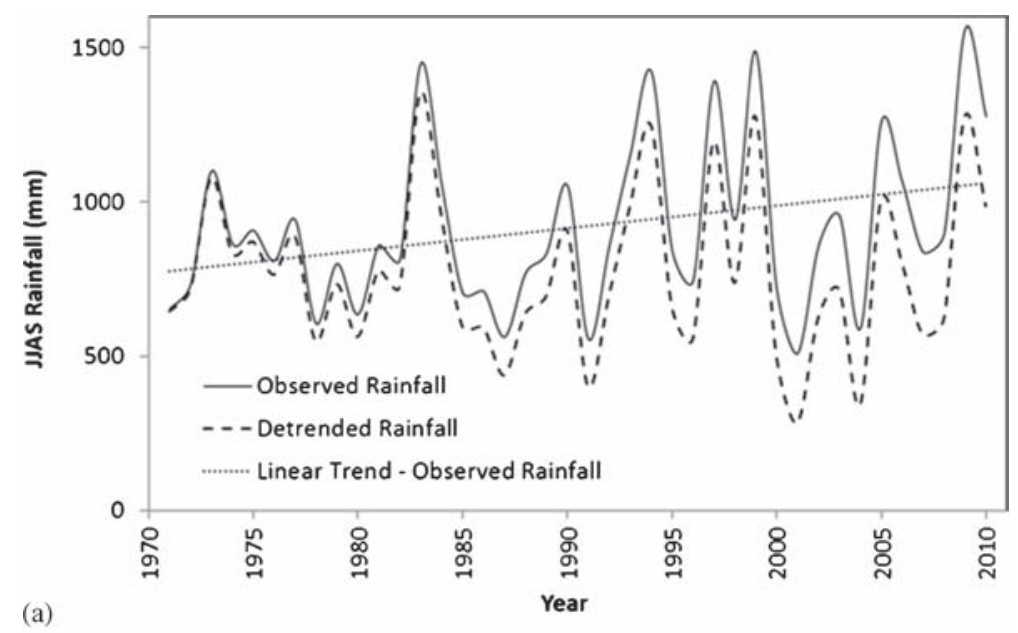

(a)

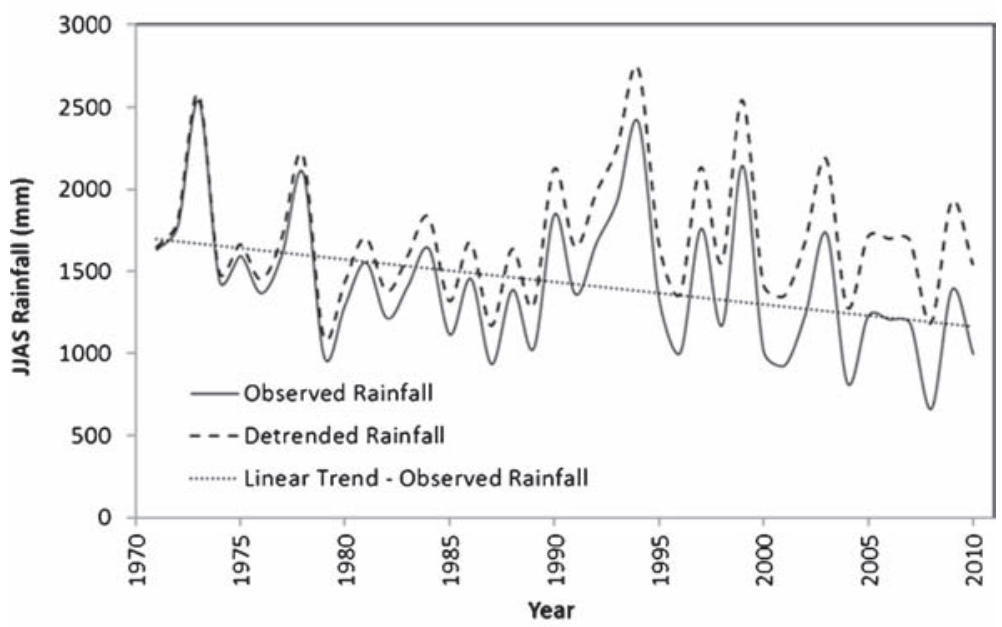

(b)

Figure 4. Statistically significant JJAS rainfall trends at single grid level over. (a) Increasing rainfall trend and (b) decreasing rainfall trend. 

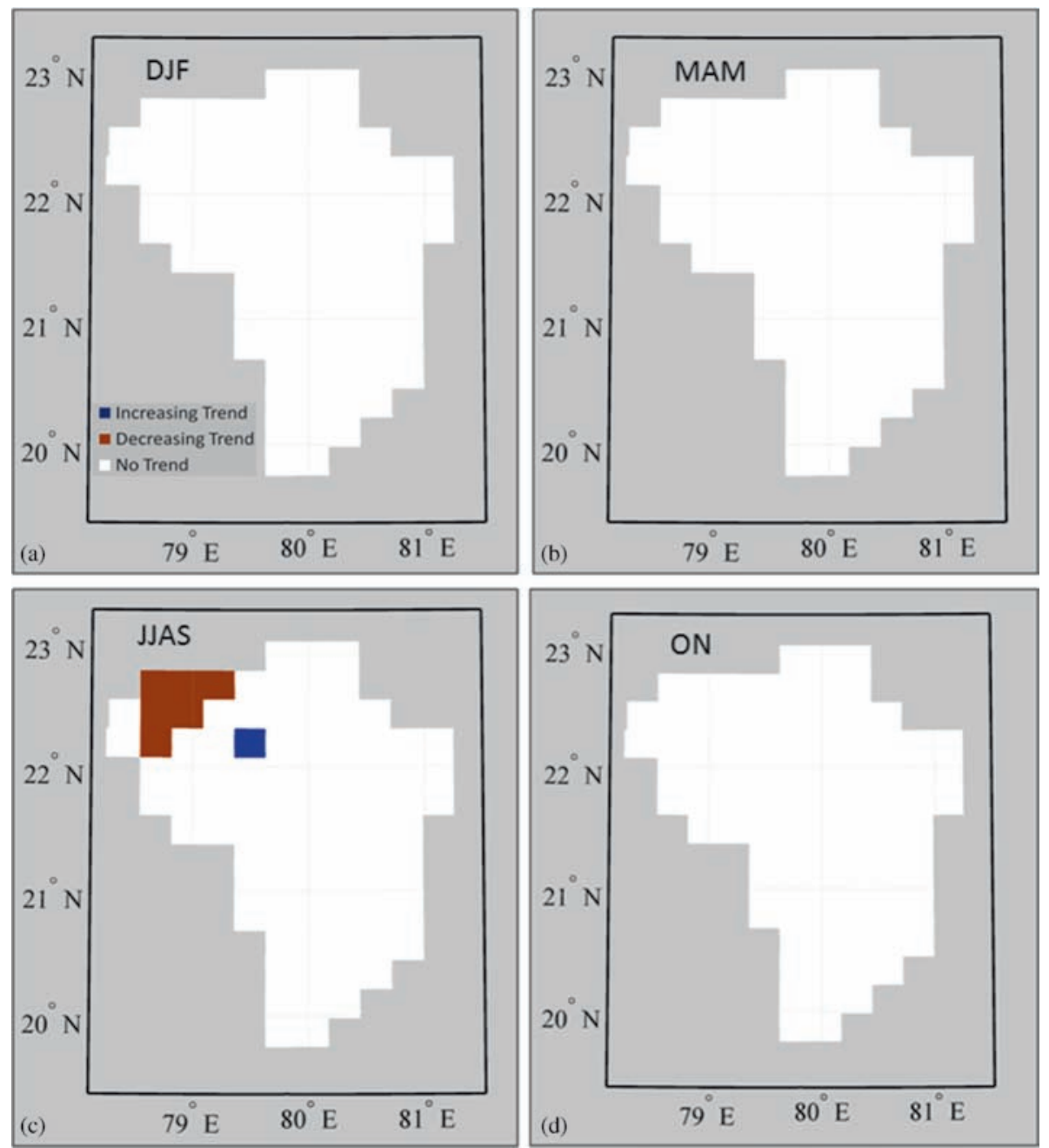

Figure 5. Statistically significant seasonal rainfall trends over Ashti Catchment. (a) DJF, (b) MAM, (c) JJAS and (d) ON.

Table 2. Range of meteorological forcing data for different scenarios.

\begin{tabular}{lcccc}
\hline Scenario & $\begin{array}{c}\text { Rainfall } \\
(\mathrm{mm})\end{array}$ & $\begin{array}{c}\text { Max. temperature } \\
\left({ }^{\circ} \mathrm{C}\right)\end{array}$ & $\begin{array}{c}\text { Min. temperature } \\
\left({ }^{\circ} \mathrm{C}\right)\end{array}$ & $\begin{array}{c}\text { Wind } \\
(\mathrm{m} / \mathrm{s})\end{array}$ \\
\hline Observed & $809-1581$ & $28.6-34$ & $20-26.75$ & $2.5-5.85$ \\
De-trended & $833-1826$ & No trend & No trend & No trend \\
\hline
\end{tabular}

Table 3. Ranges of the sensitive parameters in the VIC-2L model.

\begin{tabular}{llr}
\hline Parameter & \multicolumn{1}{c}{ Physical meaning } & Range \\
\hline$b_{\text {infilt }}$ & Soil moisture capacity curve shape parameter & $10^{-5}-0.4$ \\
$\mathrm{D}_{\mathrm{s}}$ & Fraction of D $\mathrm{D}_{\text {smax }}$ where non-linear baseflow occurs & $0-1.0$ \\
$\mathrm{D}_{\mathrm{smax}}$ & The maximum velocity of baseflow & $0-30$ \\
$\mathrm{~W}_{\mathrm{s}}$ & Fraction of maximum soil moisture where & $0-1.0$ \\
& non-linear baseflow occurs & \\
\hline
\end{tabular}

daily observed stream flows were collected at the Ashti runoff gauging station for the period of simulation (1971-2010) and compared with the daily flows simulated using the VIC model. The daily meteorological forcing data, the land cover and the soil data, as described in section 2, were prepared to simulate the water balance components at each grid of Ashti Catchment using the VIC-2L model. Mainly, four soil parameters, viz., (1) exponent of soil moisture capacity curve $\left(b_{\text {inf }}\right),(2)$ maximum velocity of base flow that occurs from the lowest soil layer $\left(\mathrm{D}_{\mathrm{m}}\right),(3)$ the fraction of $\mathrm{D}_{\mathrm{m}}\left(\mathrm{D}_{\mathrm{s}}\right)$, and (4) fraction of maximum soil moisture $\left(\mathrm{W}_{\mathrm{s}}\right)$ were considered for the calibration, as these parameters 


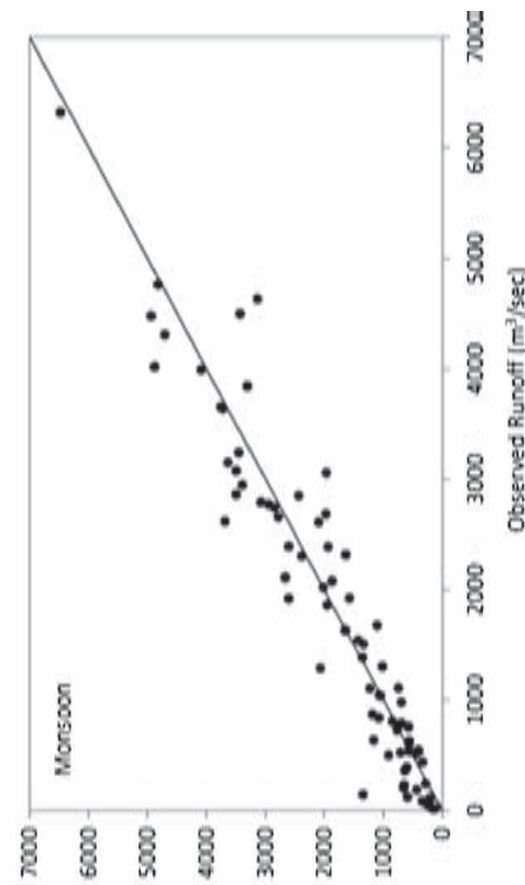

(jas/iu) joung poivinuis

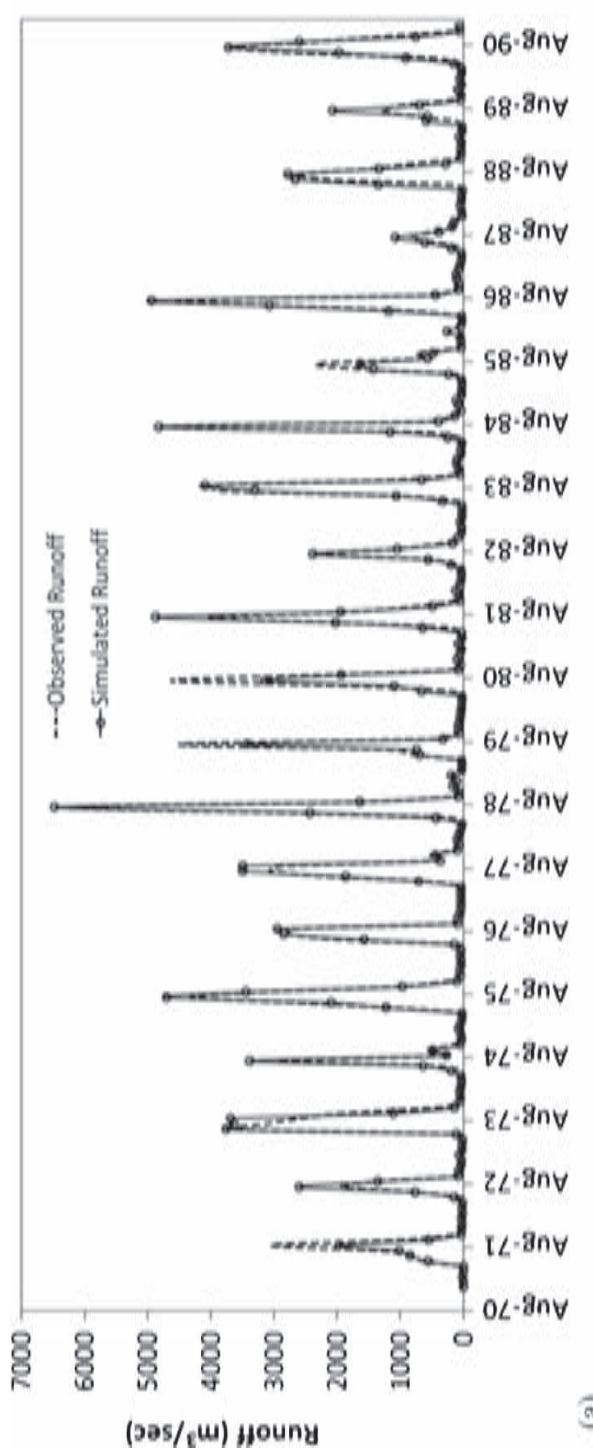

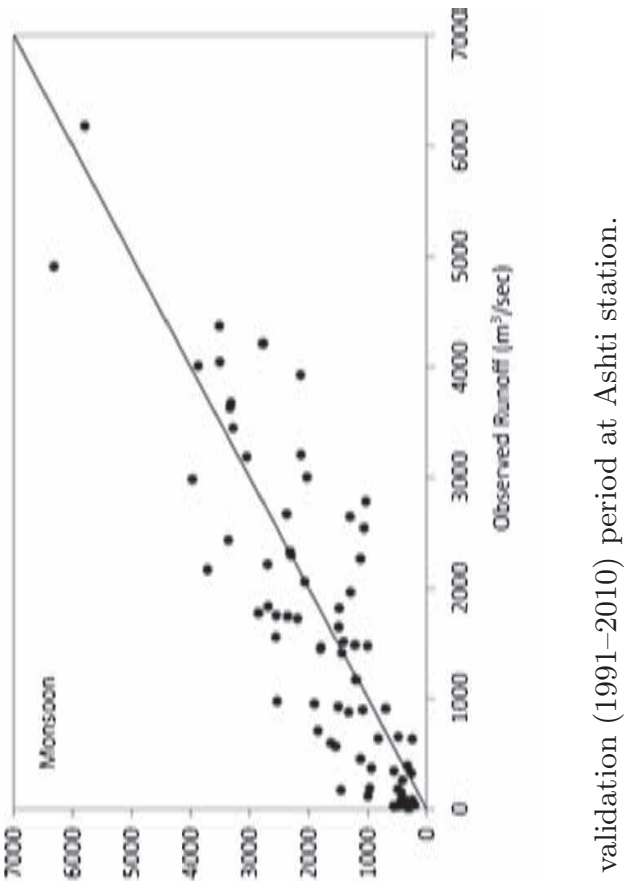

\begin{tabular}{llllllll}
8 & 8 & 8 & 8 & 8 & 8 & 8 & 8 \\
\hline
\end{tabular}

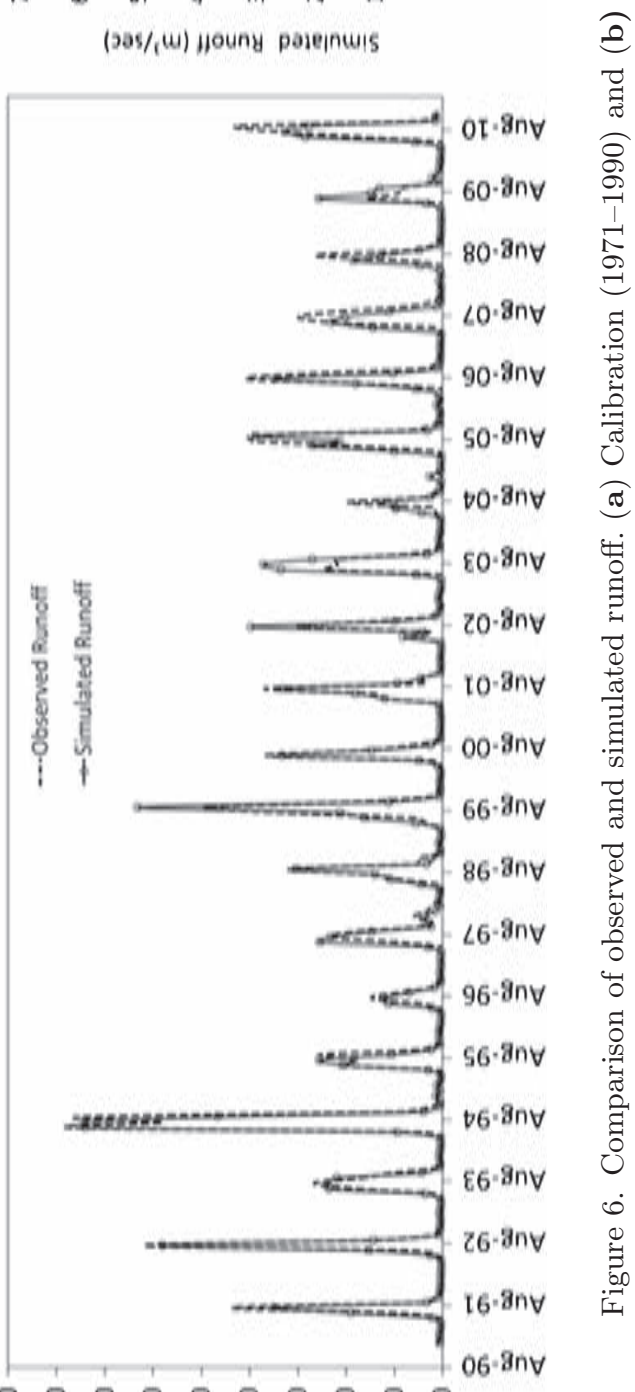

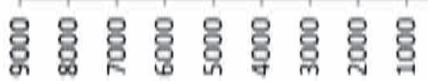


cannot be well determined based on the available soil information. The ranges of these parameters are represented in table 3 . The simulated runoff depths generated by the VIC model were routed through the river network using the routing model (Lohmann et al. 1998) to obtain the simulated stream flows at the Ashti runoff gauging station.

The model was calibrated for the period of 20 years (1971-1990) and validated for the period of next 20 years (1991-2010). The required model input parameters, as well as observed stream flows at the Ashti location, was available during this period. Figure 6 shows the comparison of observed and simulated runoff. It shows a good agreement between simulated and observed stream flows at Ashti runoff gauging station. It was proposed to evaluate and understand the model capabilities by comparing the performance indicator such as Nash-Sutcliffe coefficient $\left(N_{s}\right)$, relative error $(R E)$, and coefficient of determination $\left(R^{2}\right)$ by comparing observed and simulated stream flows. Simulation results are tabulated in table 4 . The NashSutcliffe coefficient was 0.94 , the coefficient of determination was 0.91 and the relative error was below $1.8 \%$ for the calibration period (1971-1990). The Nash-Sutcliffe coefficient was 0.86, the coefficient of determination was 0.78 and relative error was $3.71 \%$ for the validation period (1990-2010). Decrease in model efficiency was found during the validation period (1990-2010) because of slight disagreement between simulated and observed stream flows for few specific years, as shown in figure 6(b). Figure 7 shows the spatial variation of average daily observed rainfall, simulated evapotranspiration, simulated surface runoff and simulated base flow over the Ashti Catchment.

\subsection{Impact of change in rainfall trends}

As described in section 3.4, seasonal trend analysis was performed on the meteorological forcing data for the period 1971-2010. Table 5 represents the average seasonal (JJAS) evapotranspiration,

Table 4. Model performance indicators during calibration and validation.

\begin{tabular}{lcccc}
\hline Station & Period & $N_{s}$ & $R E(\%)$ & $R^{2}$ \\
\hline Ashti & $1971-1990$ & 0.94 & 1.80 & 0.91 \\
& $1991-2010$ & 0.86 & 3.71 & 0.78 \\
\hline
\end{tabular}

surface runoff and base flow for the observed and de-trended rainfall. The decrease in rainfall was observed, which caused a further decrease in the evapotranspiration, surface runoff and baseflow. It could be observed that a slight decrease in monsoon rainfall $(1.67 \%)$ caused a higher decrease in total runoff, that includes surface runoff $(7.79 \%)$, and baseflow (38.2\%). The baseflow is the part of runoff, which is governed by the thickness of bottom soil layer. The thicker bottom soil layer causes higher and longer soil moisture retention, which eventually results into higher baseflow. In the present study, the bottom soil layer $(700 \mathrm{~mm})$ is thicker than the top soil layer $(300 \mathrm{~mm})$. Hence, the higher thickness of bottom soil layer might be one of the reasons for higher baseflow. Also, the geomorphological characteristics of the catchment can be a cause for this. The decrease in evapotranspiration was less, as compared to runoff. The decreased rainfall caused a slower decreasing rate of evapotranspiration and higher decreasing rate of runoff, which is in agreement with the rate of the hydrological process. It is inferred that the model is capable of modelling different hydrological processes and respective flow rates. Hence, it could be concluded that the VIC model is able to evaluate the hydrological processes.

\subsection{Impact of land cover classes on hydrological variables}

The changes in the hydrological processes for different vegetation classes were obtained by simulating hydrological variables using AVHRR land cover (1981-1994). Figure 8 represents the significant changes in average evapotranspiration for the different land cover classes. The evapotranspiration varies from $610.9 \mathrm{~mm}$ (evergreen broadleaf) to $493.9 \mathrm{~mm}$ for cropland. It may be inferred that the evapotranspiration is the highest for forest cover (evergreen broadleaf, deciduous broadleaf and mixed forest) and the lowest for the shrubland, and cropland. Evapotranspiration is generally greater for forested catchments than for non-forested catchments (Zhang et al. 2001).

\subsection{Discussion}

For the Ashti Catchment, no statistically significant $(95 \%)$ trends were observed for meteorological

Table 5. Simulated changes in the hydrological variables due to rainfall trends.

\begin{tabular}{lccccc}
\hline Scenarios & Season & $\begin{array}{c}\text { Rainfall } \\
(\mathrm{mm})\end{array}$ & $\begin{array}{c}\text { Simulated } \\
\text { evapotranspiration }(\mathrm{mm})\end{array}$ & $\begin{array}{c}\text { Simulated surface } \\
\text { runoff }(\mathrm{mm})\end{array}$ & $\begin{array}{c}\text { Simulated } \\
\text { baseflow }(\mathrm{mm})\end{array}$ \\
\hline De-trended rainfall & JJAS & 1104.36 & 541.82 & 257.67 & 183.31 \\
Observed rainfall & JJAS & 1086.21 & 519.71 & 237.6 & 113.28 \\
Change $(\%)$ & JJAS & -1.64 & -4.25 & -7.79 & -38.2 \\
\hline
\end{tabular}



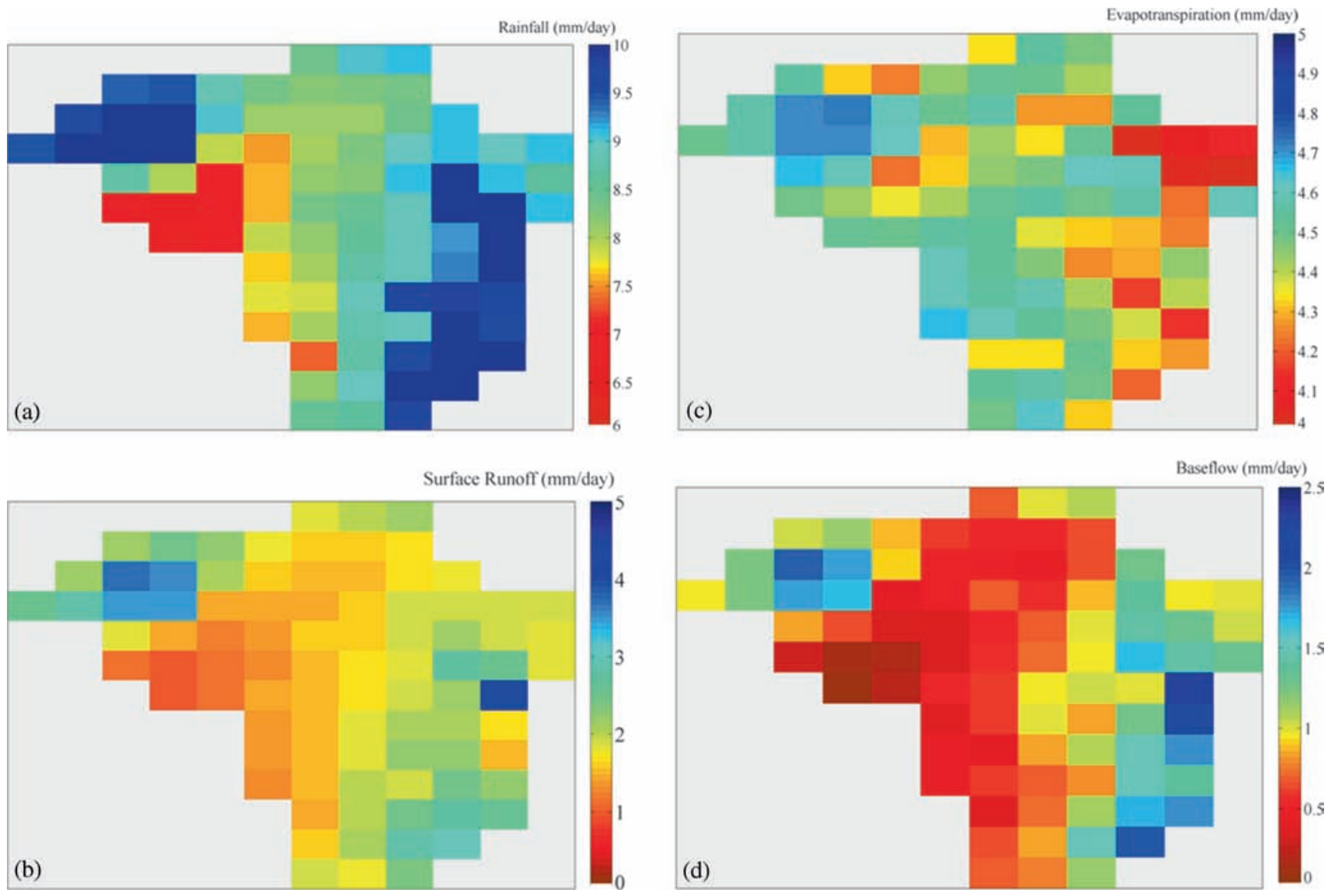

Figure 7. Spatial variation in water balance components ( $\mathrm{mm} /$ day) during monsoon period over the Ashti Catchment. (a) Rainfall, (b) surface runoff, (c) evapotranspiration and (d) baseflow.

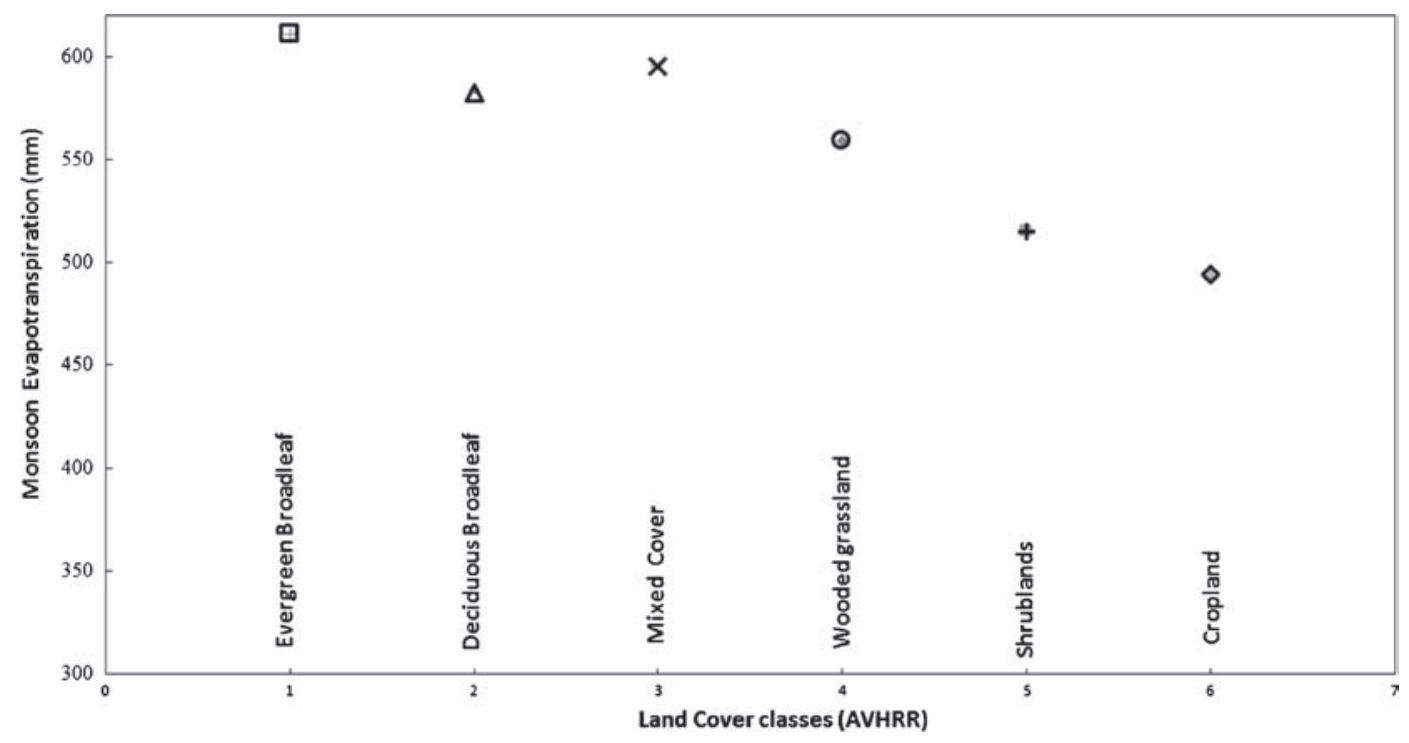

Figure 8. Evapotranspiration for different vegetation classes.

forcing data except monsoon rainfall. Only at few grid locations, decreasing monsoon rainfall trends were observed, which caused the decrease in $1.64 \%$ of average monsoon rainfall over 40 years (19712010). It could be inferred that the impact of climate change on rainfall is negligible. The slight decrease in the rainfall $(1.67 \%)$ caused a slight decrease in evapotranspiration $(4.25 \%)$ and a significant decrease in the surface runoff $(7.79 \%)$ and baseflow $(38.2 \%)$. This phenomenon is predominant 
in the case of Indian monsoon. The potential evapotranspiration is achieved during monsoon period, and hence the change in runoff is predominantly governed by rainfall.

In this study, a good agreement is observed between simulated and observed stream flows at Ashti runoff gauging station. The Nash-Sutcliffe model efficiency coefficient is generally determined to estimate the predictive power of the model. An efficiency of $1(\mathrm{E}=1)$ corresponds to a perfect match between model simulated stream flows and the observed stream flows. In the present study, the model efficiency is closer to 1 (table 4 ). The relative errors $(R E)$ were below $4 \%$ and the coefficient of determination $\left(R^{2}\right)$ ranged between 0.78 and 0.91 . The coefficient of determination $\left(R^{2}\right)$ ranges from 0.0 (indicating a poor model) to 1.0 (indicating a perfect model). Hence, the model performance indicators show that the VIC model could simulate the hydrological variables efficiently over the Ashti Catchment.

Evapotranspiration is governed by root depth, leaf area index, and other vegetation and eventually by vegetation classes. The root depth along with soil properties governs the ability of the vegetation class to draw water from the soil. Deeper root zone can draw the soil moisture from the bottom soil layer, when the soil moisture in the upper soil layer is limited. As an effect of higher evapotranspiration, the surface runoff and base flow decrease. Hence, surface runoff is directly governed by the vegetation class along with the other soil properties. It could be concluded that the change in hydrological variables is partially governed by the change in land cover class (figure 8).

It could be inferred from the above discussion that the VIC model is able to evaluate the hydrological processes such as evapotranspiration, surface runoff and baseflow reasonably for large catchments. The acceptance of input data directly from global gridded databases or GCMs and subgrid variability of land use land cover (LULC) strengthen the suitability of the VIC model in the evaluation of the hydrological implications of land use land cover (LULC) and climate change over the large catchments.

\section{Conclusions}

In this study, the implication of land cover change and rainfall trends on the hydrological processes in Ashti Catchment in India is analysed using a mesoscale hydrological model, VIC. The significant changes in the hydrological variables were evaluated and discussed. Following are the conclusions from the present study.
- The VIC model considers a large number of parameters that influence hydrological processes. The performance indicators such as NashSutcliffe coefficient $\left(N_{s}\right)$, relatively error $(R E)$, and coefficient of determination $\left(R^{2}\right)$ show a good agreement between the simulated and observed stream flows. Hence, the VIC model is able to evaluate the hydrological changes within the major catchment.

- The acceptability of the VIC model is strengthened by the readily available global or regional datasets such as meteorological forcing, land cover, soil and topography.

- Increasing, as well as decreasing, statistically significant (95\%) rainfall trends were observed at few grids of the Ashti Catchment, especially during the monsoon period. Though, very few grids showed the statistically significant $(95 \%)$ rainfall trends, decreasing rainfall trends (six grid locations) were dominant, as compared to increasing trends (one grid location). It could be concluded that the impact of climate change is not so significant on the Ashti Catchment for 40 years period (1971-2010).

- The hydrological responses of the catchment show that a slight decrease in rainfall causes a higher percentage decrease in the base flow and surface runoff and lower percentage decrease in evapotranspiration. This phenomenon is predominant for Indian monsoon, as most of the catchments/river basins receive the concentrated monsoon rainfall when potential evapotranspiration is achieved, and runoff is predominantly governed by the rainfall.

- Trees with deeper roots are able to draw the soil moisture from deeper soil layers when the soil moisture in the upper soil layer is limited. Hence, the forest cover causes higher evapotranspiration and decreased surface runoff.

\section{Acknowledgements}

The authors sincerely acknowledge Central Water Commission (CWC) for providing streamflow data at the Ashti runoff gauging station. The first author is thankful to Prof. Subimal Ghosh for his suggestions, help and valuable guidance.

\section{References}

Burns D H 2008 Climatic influences on streamflow timing in the headwaters of the Mackenzie River Basin; J. Hydrol. 352(1-2) 225-238.

Chen H, Guo S, Xu C Y and Singh V P 2007 Historical temporal trends of hydro-climatic variables and runoff response to climate variability and their relevance in water resource management in the Hanjiang basin; J. Hydrol. 344(3-4) 171-184. 
Cherkauer K A and Lettenmaier D P 1999 Hydrologic effects of frozen soils in the upper Mississippi River basin; J. Geophys. Res. 104 19,599-19,610.

FAO 2003 The digitized soil map of the world and derived soil properties (version 3.5); FAO Land and Water Digital Media Series 1, FAO, Rome.

Hurkmans R, Moel H, Aerts J C J H and Troch P A 2008 Water balance versus land surface model in the simulation of Rhine river discharges; Water Resour. Res. 44(1) 1-14.

Kalnay E, Kanamitsu M and Kistler R 1996 The NCEP/NCAR 40-years reanalysis project; Bull. Am. Meteorol. Soc. 77(3) 437-471.

Liang X, Lettenmaier D P, Wood E F and Burges S J 1994 A simple hydrologically based model of land surface water and energy fluxes for general circulation models; J. Geophys. Res. 99 14,415-14,428.

Liang X, Lettenmaier D P and Wood E F 1996 Onedimensional statistical dynamic representation of subgrid variability of precipitation in the two-layer variable infiltration capacity model; J. Geophys. Res. 101 403-421.

Lin K, Guo S, Zhang S W and Liu P 2007 A new base flow separation method based on analytical solutions of the Horton infiltration capacity curve; Hydrol. Process. 21(13) 1719-1736.

Lin K, Zhang Q and Chen X 2010 An evaluation of impacts of DEM resolution and parameter correlation on TOPMODEL modelling uncertainty; J. Hydrol. 394(3-4) 370-383.

Lohmann D, Nolte-Holube R and Raschke E 1996 A large scale horizontal routing model to be coupled to land surface parameterization schemes; Tellus A 48(5) 708721.
Lohmann D R, Raschke E, Nijssen B and Lettenmaier D P 1998 Regional scale hydrology: I. Formulation of the VIC2L model coupled to a routing model; Hydrol. Sci. J. 43 131-141.

Maurer E P, Wood A W, Adam J C, Lettenmaier D P and Nijssen B 2002 A long-term hydrologically-based dataset of land surface fluxes and states for the conterminous United States; J. Climate 15 3237-3251.

Nijssen B, Greg O'Donnell M and Lettenmaier D P 2000 Predicting the discharge of global rivers; J. Climate 14(15) 3307-3323.

Nijssen B, Greg O'Donnell M, Hamlet A F and Lettenmaier D P 2001 Hydrologic sensitivity of global rivers to climate change; Climatic Change 50 143-175.

Qiao L, Hong Y, Renee M R, Mark S, David G D, David W D, Chen S and Lilly D 2014 Climate change and hydrological response in the trans-state Oologah Lake watershed-Evaluating dynamically downscaled NARCCAP and statistically downscaled CMIP3 simulations with VIC model BCSD; Water Resour. Manag. 28 3291-3305.

Rajeevan M, Bhate J, Kale J D and Lal B 2005 Development of a high resolution daily gridded rainfall data for the Indian region: Analysis of break and active monsoon spells; Technical Report, India Meteorological Department.

Todini E 1996 The ARNO rainfall-runoff model; J. Hydrol. $175339-382$.

Zhang L, Dawes W R and Walker G R 2001 Response of mean annual evapotranspiration to vegetation changes at catchment scale; Water Resour. Res. 37(3) 701-708. 